\title{
HOMO- AND COPOLYMERIZATION OF STYRENE AND STYRENE RELATED MONOMERS. SYNTHESIS AND CHARACTERIZATION
}

\author{
FRANCO M, RABAGLIATI *, MARIA V. CUEVAS, MÓNICA. A. PÉREZ, F.J. RODRÍGUEZ, R.A. CANCINO, G. A. \\ MARDONES, H.E. MUÑNOZ, M.A. SAAVEDRA, M. VIDAL, L. A. MUÑOZ, D. A. CANALES, D. A. YAÑEZ. \\ P. A. ZAMORA, P. A. ZAPATA
}

Grupo de Polimeros. Departamento Ciencias del Ambiente, Facultad de Química y Biología. Universidad de Santiago de Chile. USACH. Casilla 40, correo 33. Santiago, Chile

\begin{abstract}
Systems including diphenylzinc, metallocene, and methylaluminoxane, at various combinations has been attempted, as initiating systems for homo- and copolymerization of styrene and various styrene related comonomers including : substituted styrenes, styrene derivatives, $\alpha$-olefins, dienes and more recently cycohexenes including norbornene. The used metallocenes were those containing titanium, zirconium and for comparatives reasons hafnium. The metallocene efficiency towards syndiotactic polystyrene polymerization showed the order : titanocene $>$ zirconocene $>$ hafnocene. While the polymerization as well the copolymerization of Styrene with related to styrene compounds resulted to be much influenced by both electrical and steric hindrance effect. For styrene substituted derivative those group or element having I+ inductive effect depending its position at styrene's its phenyl ring favours homopolymerization as well their copolymerization with styrene. The steric hindrance also showed a determinant influence on reactivity, so methyl and tert-butyl group, having a I+ effect, when at para-position improve activity and stereoregularity of their polymerization processes. But when placing at orto-position showed a very low capacity to polymerize. The present and previous results indicate that polymerization processes are initiated by monomer coordination to active metal species either of the binary metallocene-MAO or of the ternary $\mathrm{Ph}_{2} \mathrm{Zn}$-metallocene-MAO.
\end{abstract}

Keywords: Polymer synthesis - Polymer blends - Composites Polymer based, Polymer/Pharmaceutical Blends.

Partially presented at $32^{\circ}$ Congreso Latinoamericano de Química and XXXI Jornadas Chilenas de Química, Concepción, Chile, January, 19 - 22. 2016.

\section{INTRODUCTION}

By 2010 "Worldwide production of plastics" (polymers) reached ca 2,628,000 Ton/year.[1] The applications for plastics are widely recognized as essentially limitless on consequently plastics are found almost every where: Packaging, Building, and Construction Industry, Automobile Manufacture, at Home and many others applications where plastics are present. Polyethylene both low and high density, are included in most of the packaging materials. Furthermore, certain polymers (plastics) have excellent impenetrable properties acting as barriers to oxygen, water vapor, and other gases. The building (construction) industry is the second largest consumer of plastics which requires high density polyethylene, HDPE, and poly(vinyl chloride), $\mathrm{PVC}$, it is found as a wide diversity of plastics uses : pipes, sheets, wives to entire buildings, roofing materials, door and windows frames, mounding screws, and hardware. Also a variety of plastics are used in the manufacture of automobiles, trucks, buses, trains, airplanes and chips. Electronic devices it is also a wide field where plastics are used. The wives of almost all electronic devices are encased in some type of plastic, outer casing of telephones, lighting fixture, electronic mixer housing, fans, radio cabinets, computers, clocks and many other. In any home there are plenty pieces made of plastics.

The incorporation of plastic into modern medicine has steadily increased in the last decade. Plastics have contributed to a reduction in medical costs, infectious disease and pain management. High tech polymers are used to create new and improved artificial limbs and plastic disposable delivery devices have succeeded in reducing the risk of infection to patients. Patients directly benefit from the use of plastic with more lives being saved, improved and prolonged due to its use.

Conventional or commercial polystyrene, also called General Purpose Polystyrene is one of the most employed worldwide polymer, actually one of the most employed polymer, after polyethylene, polypropylene and poly(ethylene terephthalate), according worldwide plastics production in 2011. [1] Commercial polystyrene is an inexpensive polymer with reliable properties: is a good electrical insulator, has excellent optical clarity and is easy to process. Anyhow it has some deficiencies : it is attacked by organic solvents, is a rather poor barrier to oxygen and water and has a relatively low melting point. Furthermore PS is very low to biodegrade and therefore is a focus of controversy among environmentalists.

Our group, since the early nineties has been dedicated to the synthesis and characterization of polymers mainly working with styrene and styrene related compounds. Both styrene homopolymerization and also copolymerization of styrene/(styrene derivative), styrene/alkene, styrene/diene, styrene/cycloalkene copolymerization, through metallocenic polymerization; [5-11,13] in the last years, with incorporation of Dr. Paula Zapata, our research group has performed successfully researches in nanoparticles and nanocomposites. [12 a,b]. Finally most recent research works on polymer-pharmaceutical composites has been developed $[14,15]$

\section{EXPERIMENTAL}

Homo- and copolymerization experiments were carried out in an argon atmosphere in a $100 \mathrm{~cm}^{3}$ Schlenk tube equipped with a magnetic stirrer. Toluene solvent, $\mathrm{MAO}$ solution, $\mathrm{Ph}_{2} \mathrm{Zn}$ solution, and metallocene solution in toluene were sequentially charged by syringe under argon pressure. Polymerization was initiated by injecting the styrene or simultaneously the required amount of $\mathrm{S}$ and comonomer. The reactions were kept at $60{ }^{\circ} \mathrm{C}$ with stirring for the required length of time. Polymerization was ended by adding a mixture of hydrochloric acid and methanol. The polymers, coagulated in the acidified methanol, were recovered by filtration, were washed several times with methanol, and dried under vacuum at $60^{\circ} \mathrm{C}$.

Intrinsic viscosity, $|\eta|$, was measured in o-dichlorobenzene at $135^{\circ} \mathrm{C}$, or at $25^{\circ} \mathrm{C}$ in chloroform for a-PS (amorphous), and was determined by the onepoint method. [16]

Differential scanning calorimetry, DSC, analyses were performed by using a Rheometric Scientific DSC apparatus with the samples placed under a nitrogen atmosphere, at a rate of $10{ }^{\circ} \mathrm{C} \mathrm{min}-1$ and after cooling to room temperature, reheated at the same rate. The reported $\mathrm{T}_{\mathrm{g}}$ and $\mathrm{T}_{\mathrm{m}}$ were those obtained in the second scan.

${ }^{13} \mathrm{C}$-NMR spectra, in 1,1,2,2-tetrachloroethane- $\mathrm{d}_{2}$ at $60^{\circ} \mathrm{C}$, were recorded on a Bruker Avance-400 spectrometer operating at $100.61 \mathrm{MHz}$. Chemical shifts calibrated against tetra-methylsilane, TMS.

\section{RESULTS AND DISCUSSION}

Polystyrene, PS, is a synthetic aromatic polymer made from monomer styrene. Commercial polystyrene, also called: General Purpose Polystyrene is clear, hard, and rather brittle. It is a low cost resin per unit weight. It is rather a poor barrier to oxygen and water vapor and has a relatively low melting point. The synthesis of s-PS has received much attention from academy and also from industry researchers resulting a considerable number of papers and studies having styrene as its model. By 1945 G. Natta and K. Ziegler introduce the term tacticity (atactic, isotactic, and sindiotactic polymers) to describe stereoregular polymers, as it is the case of polystyrene, polypropylene and 
others, to name the possible configuration of their stereoregular polymers.

Years late, Ishihara et al, [2] published the discovery of a special type of polystyrene, s-PS. By that time Italian researcher also announced a similar success: Pellecchia et al. [3] Since then, there was much interest from both academy and industry for this sort of PS and a considerable number of papers were produced on special synthesis of stereoregular syndiotactic polystyrene; describing new catalysts for its stereoregular synthesis. [19]

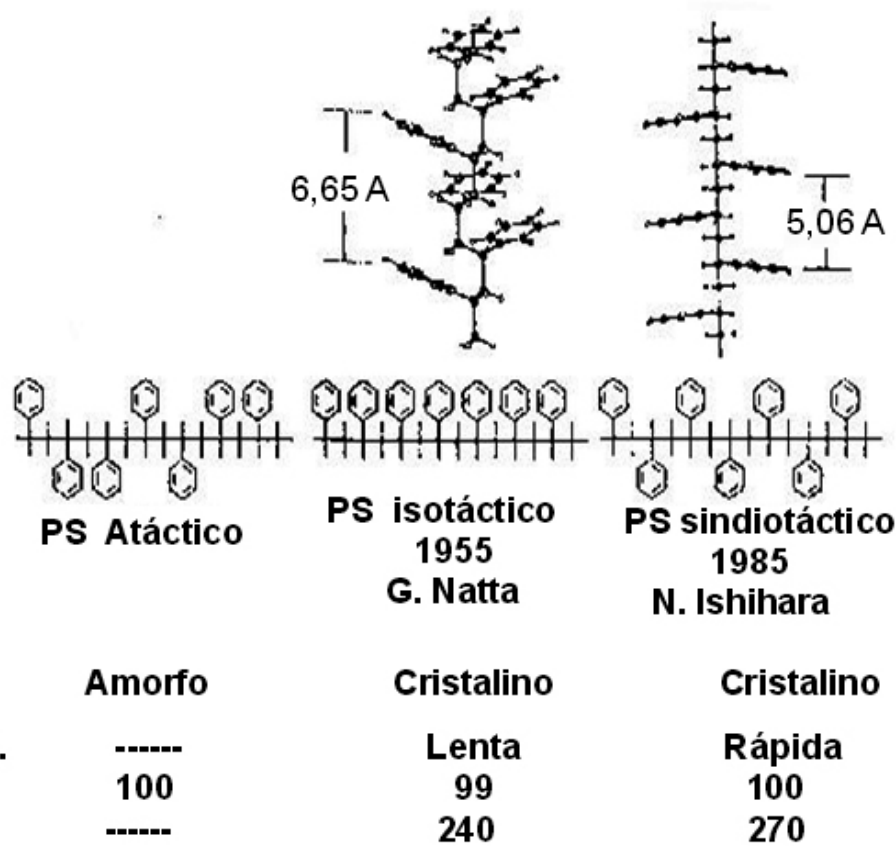

Figure 1. Structure, disposition and thermal properties of atactic, isotactic and syndiotacticpolystyrene.

Veloc. Cristn.

$\mathrm{Tg},\left({ }^{\circ} \mathrm{C}\right)$

$\mathrm{Tm},\left({ }^{\circ} \mathrm{C}\right)$ sindiotactico

Cristalino

100

270

\section{(A)Metallocenes}

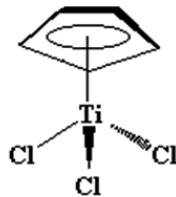

Cl

$\mathrm{CpTiCl}_{3}$

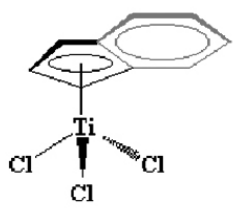

IndTiCl

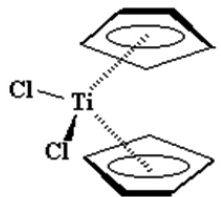

$\mathrm{Cp}_{2} \mathrm{TiCl}$

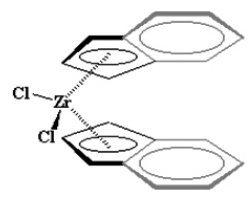

$\mathrm{Ind}_{2} \mathrm{ZrCl}$

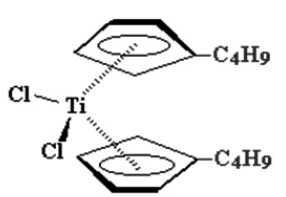

(n-BuCp) ${ }_{2} \mathrm{TiCl}_{2}$

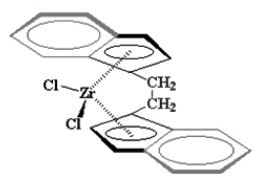

$\mathrm{Et}(\mathrm{Ind})_{2} \mathrm{ZrCl}_{2}$
(B) MethylalumInoxane
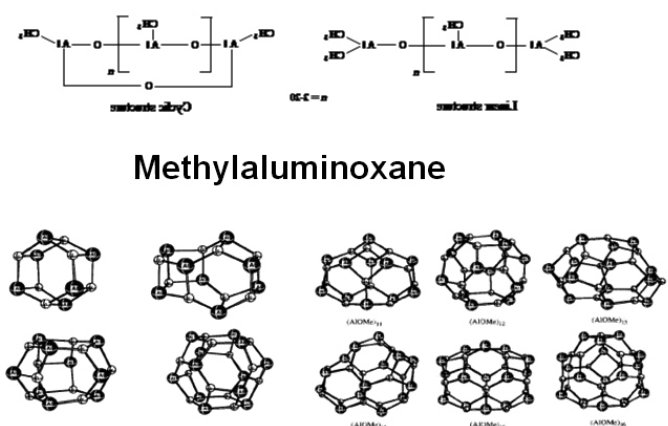

Barros et al.

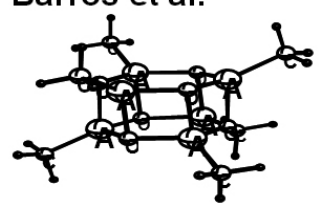

Ziegler et al

\section{Kaminsky and Sinn}

Figure 2. Structure of A) Some metallocenes and B) Methylaluminoxane and its cyclic structure postulated by Barros et al., F. Ziegler et al., and by Kaminsky and Sinn. 
Figure 1 summarize the characteristics of the three known forms of polystyrene according to its stereoregularity. There, are shown their structures and some properties basically the placements of aromatic ring of styrene repeating units along the polymer chain, which geometry made the particular characteristic of each configuration (atactic, isotactic and syndiotactic). From Fig. 1 it is appreciated that all the three PS have practically the same glass temperature $\left(\mathrm{Tg}=99-100{ }^{\circ} \mathrm{C}\right)$ but quite different ceiling temperature in agreement with its capacity of crystallization. Atactic-PS being amorphous does not present $\mathrm{Tm}$ value, while the other two, show both: $\mathrm{Tg}$ and $\mathrm{Tm}$. $\left(\mathrm{Tm}_{\mathrm{i}}\right.$ $\mathrm{PS}=240$ and $\mathrm{Tm}_{\mathrm{s}-\mathrm{PS}}=270^{\circ} \mathrm{C}$ ). Anyhow there is an important difference between them : i-PS has a low rate of crystallization which make it with no commercial interest.
At figure 2A are shown some metallocenes as well as its more employed cocatalyst (Fig, 2B), methylaluminoxane. For which its real structure it is not complete cleared. So as example are shown the structures suggested by various authors.

Table 1 , shows a series of ternary $\mathrm{Ph}_{2} \mathrm{Zn}$-Metallocene.MAO styrene's polymerization initiator systems, where are included pertinent parameters of the systems studied by us in preliminary experiments. From there it is possible compare the efficiency of each ternary $\mathrm{Ph}_{2} \mathrm{Zn}$-Metallocene-MAO initiating system including polymerization conditions as indicate at bottom notes of this Table.

From Table 1, it is noted that PS obtained when catalyzed through zirconocene produce crude PS with none content of insoluble in boiling butanone, or at the best only low percentages (3.4 and $15.6 \%$ ) of insoluble polymer in boiling

Table 1.Polymerization of styrene by $\mathrm{Ph}_{2} \mathrm{Zn}-\mathrm{Met}-\mathrm{MAO}$ initiator systems, in toluene after $48 \mathrm{~h}$ at $60{ }^{\circ} \mathrm{C}$, a)

\begin{tabular}{|c|c|c|c|c|c|c|c|}
\hline \multirow{2}{*}{ Run } & \multirow{2}{*}{ Initiator system } & \multirow{2}{*}{$\begin{array}{c}\text { Activity } \\
\text { (PS-Kg/Met-mol x } \\
\text { S-mol x hour) }\end{array}$} & \multirow{2}{*}{$\begin{array}{c}|\eta|^{\mathbf{b}} \\
\mathrm{dL} / \mathrm{g} \\
\end{array}$} & \multirow{2}{*}{$\begin{array}{c}\mathrm{M}_{\mathrm{v}} \times 10^{-4} \\
\mathrm{~g} / \mathrm{mol} \\
\end{array}$} & \multicolumn{2}{|c|}{ DSC } & \multirow{2}{*}{$\begin{array}{c}\text { Insoluble } \\
\text { Fraction } \\
\% \\
\end{array}$} \\
\hline & & & & & $\begin{array}{l}\mathrm{T}_{\mathrm{m}} \mathbf{1} \\
{ }^{\circ} \mathrm{C} \\
\end{array}$ & $\begin{array}{c}\mathrm{T}_{\mathrm{m}} 2 \\
{ }^{\circ} \mathrm{C} \\
\end{array}$ & \\
\hline 2 & $\mathrm{Ph}_{2} \mathrm{Zn}-\mathrm{Cp}_{2} \mathrm{ZrCl}_{2}-\mathrm{MAO}$ & 3.51 & $0.19^{\mathrm{b}}$ & 2.7 & None & None & n.d. \\
\hline 3 & $\mathbf{P h}_{2} \mathrm{Zn}-(\mathrm{MeCp})_{2} \mathrm{ZrCl}_{2}-\mathrm{MAO}$ & 8.74 & $0.14^{\mathrm{b}}$ & 1,8 & None & None & n.d. \\
\hline 5 & $\mathbf{P h}_{2} \mathrm{Zn}-\mathrm{Ind}_{2} \mathrm{ZrCl}_{2}-\mathrm{MAO}$ & 14.79 & $0.37^{\mathrm{b}}$ & 6.6 & None & None & 15.6 \\
\hline 6 & $\mathrm{Ph}_{2} \mathrm{Zn}$-( $\left.\mathrm{H}_{4}-\mathrm{Ind}\right)_{2} \mathrm{ZrCl}_{2}-\mathrm{MAO}$ & 3.10 & $1.80^{\mathrm{b}}$ & 57.8 & None & None & n.d.. \\
\hline 7 & $\mathrm{Ph}_{2} \mathrm{Zn}-\mathrm{Cp}_{2} \mathrm{TiCl}_{2}-\mathrm{MAO}$ & 11,34 & $0.19^{c}$ & n.d. & 246.1 & 259.7 & $86.4^{\mathrm{d}}$. \\
\hline 8 & $\mathrm{Ph}_{2} \mathrm{Zn}-(\mathrm{n} \cdot \mathrm{BuCp})_{2} \mathrm{TirCl}_{2}-\mathrm{MAO}$ & 15,77 & $0.20^{c}$ & n.d. & 249.4 & 266.0 & $91.0^{\mathrm{d}}$ \\
\hline
\end{tabular}

a Polymerization conditions: Total volume $=60 \mathrm{~mL} ; \mathrm{S}=2.0 \mathrm{~mol} / \mathrm{L} ; \mathrm{MAO}=0.33 \mathrm{~mol} / \mathrm{L}$;

Met $=2,0 \mathrm{E}-4 \mathrm{~mol} / \mathrm{L}$, Met $/ \mathrm{Ph} 2 \mathrm{Zn}=1 / 1 \mathrm{~mol} / \mathrm{mol}$. ${ }^{\mathrm{b}}$ Measured in chloroform at $25^{\circ} \mathrm{C}$

${ }^{\mathrm{c}}$ Measured in o-dichlorobencene $135^{\circ} \mathrm{C}$, ${ }^{\mathrm{d}}$ These fractions are essentially s-PS butanone, say a low content of s-PS which it is also detected by DSC analyses. By the other hand, when the ternary system $\mathrm{Ph}_{2} \mathrm{Zn}$-metallocene-MAO includes a titanocene (run 7 and 8 ) a high percentage of crystalline PS is produced (86.4 and $91.0 \%)$.

Table 2.Ternary $\mathrm{Ph}_{2} \mathrm{Zn}-\mathrm{Cp}_{2} \mathrm{TiCl}_{2}-\mathrm{MAO}$ initiating system in toluene after 48 hours at $60{ }^{\circ} \mathrm{C}$. ${ }^{\mathrm{a}}$.

\begin{tabular}{|c|c|c|c|}
\hline $\begin{array}{c}\mathbf{C}_{2} \mathbf{T i C l}_{2} / \mathbf{P h}_{2} \mathbf{Z n} \\
\mathbf{m o l a r} \mathbf{r a t i o} \\
\mathbf{m o l} / \mathbf{m o l}\end{array}$ & $\begin{array}{c}\text { Yield } \\
\mathbf{\%}\end{array}$ & $\begin{array}{c}|\boldsymbol{\eta}|^{\mathbf{b}} \\
\mathbf{d L} / \mathbf{g}\end{array}$ & $\begin{array}{c}\text { Insoluble } \\
\text { Friction } \\
\mathbf{\%}\end{array}$ \\
\hline 0.25 & 2.76 & 0.19 & 59.8 \\
\hline 0.50 & 4.48 & 0.17 & 65.4 \\
\hline 0.75 & 6.40 & 0.19 & 67.5 \\
\hline 1.00 & 9.44 & 0.28 & 58.3 \\
\hline
\end{tabular}

a) Polymerization cond it ions: Total volume $=60 \mathrm{~mL} ; \mathrm{S}=2.0$ $\mathrm{mol} / \mathrm{L} ; \mathrm{MAO}=0.33 \mathrm{~mol} / \mathrm{L} ;{ }_{2} \mathrm{TiCl}_{2}=2,08 \mathrm{E}-04 \mathrm{~mol} / \mathrm{L}$

b) Measured in o-dichlorobencene at $135^{\circ} \mathrm{C} .^{\text {c) }} \mathrm{s}$-PS, insoluble in boiling butanone.

Table 2 analyses the effectiveness of ternary initiator system at various molar ratios $\mathrm{Cp}_{2} \mathrm{TiCl}_{2} /$ Diphenylzinc $\left(\mathrm{Met} / \mathrm{Ph}_{2} \mathrm{Zn}\right)$ and their behavior in front to conversion (Yield \%) on styrene homopolymerization catalyzed through ternary $\mathrm{Ph}_{2} \mathrm{Zn}-\mathrm{Cp}_{2} \mathrm{TiCl}_{2}-\mathrm{MAO}$ initiator systems. Results indicate that conversion to polymer increases as $\mathrm{Cp}_{2} \mathrm{TiC}_{2}$ increases reaching its major yield $(9.44 \%)$ when molar ratio $\mathrm{Met} / \mathrm{Ph}_{2} \mathrm{Zn}=1.0$. While the insoluble in boiling butanone polymer fraction, say the content of s-PS, show lower variation : 60 , $65,68,58 \%$ accordingly the respective molar ratio $\mathrm{Met} / \mathrm{Ph}_{2} \mathrm{Zn}=0.25-0.50-$ 0.75 and $1.0 \mathrm{~mol} / \mathrm{mol}$ employed.

Table 3 shows the homopolimerization of styrene using some combined diphenylzinc-metallocene-MAO initiator systems where are compared a titanocene $\left(\mathrm{Cp}_{2} \mathrm{TiCl}_{2}\right)$ with a circonocene ( $\left.\mathrm{Ind}_{2} \mathrm{ZrCl}_{2}\right)$ with variable molar ratio diphenylzinc / metallocene. Results indicate that conversion to polymer and content of insoluble in boiling butanone (s-PS) are affected according this ratio. Anyhow, yield resulted the same when this ratio was near to 1.0. But the percentage of insoluble in boiling butanone, say the obtaintion of s-PS was 68.0
$\%$ for the ternary system including the titanocene $\left(\mathrm{Cp}_{2} \mathrm{TiCl}_{2}\right)$,. Furthermore, the obtained product was insoluble while the product obtained for the zirconocene, which was soluble in chloroform (see $|\eta|$, indicate absence of s-PS or only very low percentage of s-PS. In both cases a last entry was also included: some water was incorporated at the ternary initiator system: $\mathrm{H}_{2} \mathrm{O} / \mathrm{Ph}_{2} \mathrm{Zn}=1.0 \mathrm{~mol} /$ mol, which did not produce major changes at the parameter studied. 
Table 3. Homo-Polymerization of styrene initiated by combined system $\mathrm{Ph}_{2} \mathrm{Zn}$-Metallocene -MAO including $\mathrm{Cp}_{2} \mathrm{TiCl}_{2}$ and $\mathrm{Ind}_{2} \mathrm{ZrCl}_{2}$, in toluene at $60{ }^{\circ} \mathrm{C}$ after 48 hours at $60^{\circ} \mathrm{C}$. a)

\begin{tabular}{|c|c|c|c|c|c|c|c|c|}
\hline $\begin{array}{l}\text { Initiator } \\
\text { Sytem }\end{array}$ & $\begin{array}{c}{\left[\mathrm{Ph}_{2} \mathrm{Zn}\right]} \\
\mathbf{M x 1 0}^{4}\end{array}$ & $\begin{array}{c}{\left[\mathrm{Ind}_{2} \mathrm{ZrCl}_{2}\right]} \\
\mathbf{M x 1 0 ^ { 4 }}\end{array}$ & 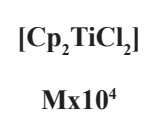 & $\begin{array}{l}\text { [MAO] } \\
\mathbf{M x 1 0}^{2}\end{array}$ & $\begin{array}{c}\text { Yield } \\
\%\end{array}$ & $\begin{array}{c}|\boldsymbol{\eta}| \\
d L / g\end{array}$ & $\begin{array}{c}\mathbf{M}_{\mathrm{v}} \\
\mathrm{g} / \mathrm{mol}\end{array}$ & $\begin{array}{l}\text { Insolubled }^{\mathrm{d}} \\
\text { Fraction }^{\text {in Boiling }} \\
\text { MeCOEt.\% }\end{array}$ \\
\hline ---/Zr//MAO & None & 3.44 & None & 33.6 & 9.07 & $0.08^{b}$ & 0.86 & $13-0$ \\
\hline $\mathrm{Zn} / \mathrm{Zr} / \mathrm{MAO}$ & 2.11 & 1.75 & None & 33.6 & 9.59 & $0.13^{b}$ & 1.50 & 7.0 \\
\hline $\mathrm{Zn} / \mathrm{Zn} / \mathrm{Zr} / \mathrm{MAO}$ & 4.21 & 3.48 & None & ---- & 0.56 & $0.70^{b}$ & 15.82 & n.d. ${ }^{\mathrm{f}}$ \\
\hline $\begin{array}{c}\mathrm{Zn} / \mathrm{Zn} / \mathrm{Zr} / \\
\mathrm{MAO}^{\mathrm{e})}\end{array}$ & 4.21 & 8.48 & None & ---- & 0.07 & n. $d^{\mathrm{f}}$ & n.d. ${ }^{\mathrm{f}}$ & n.d. ${ }^{f}$ \\
\hline --/Ti// MAO & None & None & 4.08 & 32.9 & 1,75 & n.d. ${ }^{f}$ & n.d. ${ }^{\mathrm{f}}$ & 33.1 \\
\hline $\mathrm{Zn} / \mathrm{Ti} / \mathrm{MAO}$ & 2.09 & None & 2.11 & 33.8 & 6.68 & n.d. ${ }^{\mathrm{f}}$ & n.d. ${ }^{f}$ & 68.0 \\
\hline $\mathrm{Zn} / \mathrm{Ti} / \mathrm{MAO}$ & 4.96 & None & 4.06 & ---- & 2.65 & $0.76^{\mathrm{c}}$ & 17.57 & 1.7 \\
\hline $\mathrm{Zn} / \mathrm{Ti} / \mathrm{MAO}^{\mathrm{e})}$ & 4.06 & None & 4.06 & ---- & 3.20 & $0.68^{\mathrm{c}}$ & 15.26 & 3.0 \\
\hline
\end{tabular}

a) $[\mathrm{S}]=2.0 \mathrm{M} ; \quad \mathrm{Zn}=\mathrm{Ph}_{2} \mathrm{Zn} ; \quad \mathrm{Zr}=\mathrm{Ind}_{2} \mathrm{ZrCl}_{2} ; \quad \mathrm{Ti}=\mathrm{Cp}_{2} \mathrm{TiCl}_{2}$; Based on initial $\mathrm{S}$, b) Measured in chloroform at $25^{\circ} \mathrm{C}$, ${ }^{\mathrm{c})}$ Measured in o-dichlorobenzene at $135^{\circ} \mathrm{C}$ d) insoluble in boiling butanone,

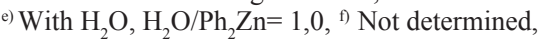

At Figures 3 and 4 are shown the ${ }^{13} \mathrm{C}$-NMR spectra of PS obtained with ternary initiator systems including the metallocene $\mathrm{Ind}_{2} \mathrm{ZnCl}_{2}$ at $\mathrm{Fig} .3$ and $\mathrm{Cp}_{2} \mathrm{TiCl}_{2}$ at Fig.4. the spectrum of the crude PS (Fig. 3a) shows several peaks in the range 145.2-146.9 ppm, while the spectrum of the insoluble in boiling butanone (Fig. 3b) shows a single peak at $145.416 \mathrm{ppm}$. These spectra showed a very good concordance with the spectra shown by Ishihara et al. [17] According to spectra crude PS is mainly atactic PS and insoluble fraction in boiling butanone is s-PS. Figure 4 shows DSC spectra

for PS obtained including the $\mathrm{Cp}_{2} \mathrm{TiCl}_{2}$ metallocene, as it is noted the spectrum of crude PS (Fig. 4a) shows two peaks at 145.577 and at $145.419 \mathrm{ppm}$ while the insoluble in boiling butanone sample shows only a single signal at $145.422 \mathrm{ppm}$. These DSC analyses are indicative of the presence of two kinds of PS and suggest the possibility of the presence of at least two kinds of active species in the course of polymerization process or two form of crystallization for s-PS

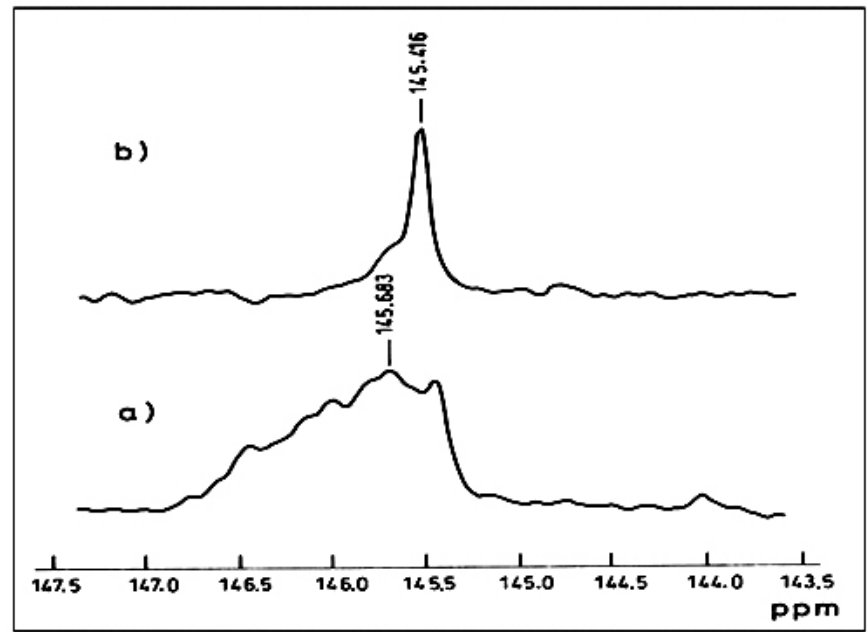

Figure $3 \cdot{ }^{13} \mathrm{C}-\mathrm{NMR}$ spectra of PS obtained with $\mathrm{Ph}_{2} \mathrm{Zn}$ - $\mathrm{Ind}_{2} \mathrm{ZnCl}_{2}-\mathrm{MAO}$ initiating system a) crude polymer; b) insoluble in boiling butanone fraction.

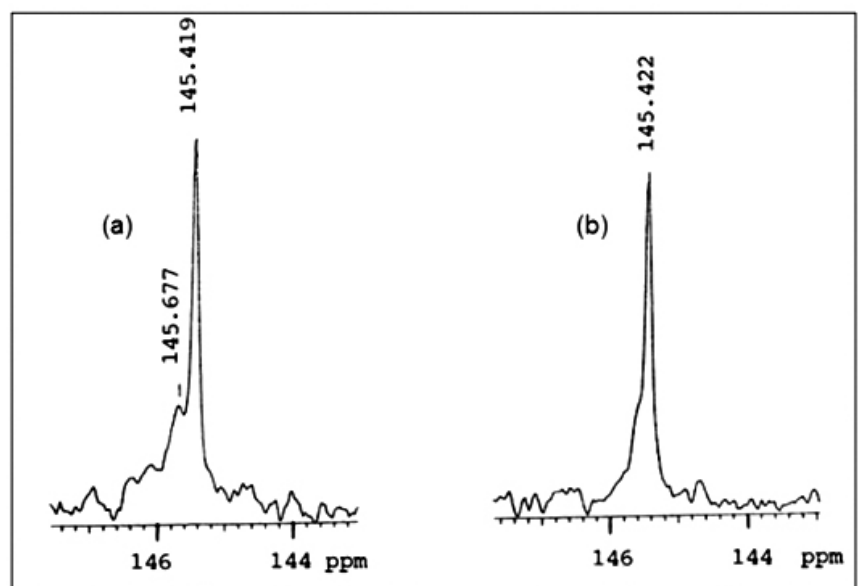

Figure $4 .{ }^{13} \mathrm{C}-\mathrm{NMR}$ spectra of PS obtained with $\mathrm{Ph}_{2} \mathrm{Zn}-\mathrm{Cp}_{2} \mathrm{TiCl}_{2}-\mathrm{MAO}$ initiating system, a) crude polymer; b) insoluble in boiling butanone Fraction

Table 4 shows the homopolimerization of styrene using various $\mathrm{Ph}_{2} \mathrm{Zn}$ metallocene-MAO initiator systems where are compared zirconocenes and titanocenes. Bis-cyclopentadienyl titanium dichloride : $\mathrm{Cp}_{2} \mathrm{TiCl}_{2}$ and bis $(\mathrm{n}-$ butylcyclopentadienyltitanium dichloride : $(\mathrm{n}-\mathrm{BuCp})_{2} \mathrm{TiCl}_{2}$ (run: 10 and 11) showed conversion to PS in an order near to zirconocene (runs: 4 and 7 ) which can be considered the result of a possible sort of steric influence due to a similar cyclopentadienyl-metal-cyclopentadienyl angle (two cyclic organic ligand bonded at metal titanium or zirconium) particularly when indenyls are the ligand. On the other hand the initiator $\mathrm{Ph}_{2} \mathrm{Zn}-\mathrm{CpTiCl}_{3}-\mathrm{MAO}$ (run 12, only one cyclopentadienyl link) turned out to be the most effective of the series $(45,7 \%$ conversion) which yield more than 5 times higher than the zirconocene (run 4), say a similar situation for metallocene based on bis-indenyl zirconium dichloride) or the run, with two ligand (Pr- and Flu-) at circonium dichloride (run 7). On the other hand, the initiator system $\mathrm{Ph}_{2} \mathrm{Zn}-\mathrm{CpTiCl}-\mathrm{MAO}$ (run 12), only one cyclopentadienyl metal-link, $\mathrm{Cp}$-Ti) turned out to be the most effective of the series $(45.7 \%$ conversion) which yield is more than 5 times higher than the zirconocene $\mathrm{Ph}_{2} \mathrm{Zn}$-Ind $\mathrm{ZnCl}_{2}-\mathrm{MAO}$ (run 4), with $8.3 \%$ conversion, approximately similar to the mentioned titanocene. A similar situation it is also present at run 7 with two ligand at metal. 
Table 4. Initiator systems used in metallocenic polymerization of styrene in toluene at $60{ }^{\circ} \mathrm{C}$ after 48 hours. a)

\begin{tabular}{|c|c|c|c|c|c|c|c|c|}
\hline Run & Initiator System & $\begin{array}{c}\text { Polymer } \\
\text { Convn } \\
\%\end{array}$ & $\begin{array}{l}|n|^{(c)} \\
\mathrm{dL} / \mathrm{g}\end{array}$ & $\begin{array}{l}\mathrm{M}_{\mathrm{v}} \\
\mathrm{x} 10^{-5} \\
\mathrm{~g} / \mathrm{mol}\end{array}$ & $\begin{array}{l}\mathrm{T}_{\mathrm{g}} \\
{ }^{\circ} \mathrm{C}\end{array}$ & $\mathrm{T}_{{ }^{\mathrm{m}}}(1)$ & $\begin{array}{c}\mathrm{T}_{\mathrm{m}}(2) \\
{ }^{\circ} \mathrm{C}\end{array}$ & $\begin{array}{l}\text { Insol. } \\
\text { Fractn }^{\text {d) }}\end{array}$ \\
\hline 1 & $\mathrm{Ph}_{2} \mathrm{Zn}$ & 0.53 & 2.13 & 7.25 & 108.9 & n.s. & n.s. & n.d. \\
\hline 2 & $\mathrm{Ph}_{2} \mathrm{Zn}-\mathrm{MAO}$ & 8.60 & 0.21 & 0.31 & 99.2 & n.s. & n.s. & n.d. \\
\hline 3 & $\mathrm{Ph}_{2} \mathrm{Zn}-\mathrm{Cp}_{2} \mathrm{ZrCl}_{2}-\mathrm{MAO}$ & 1.04 & 0.17 & 0.23 & n.d. & n.d. & n.d. & n.d. \\
\hline 4 & $\mathrm{Ph}_{2} \mathrm{Zn}-\mathrm{Ind}_{2} \mathrm{ZrCl}_{2}-\mathrm{MAO}$ & 8.30 & 0.19 & 0.32 & 102.9 & n.s. & n.s. & 15.6 \\
\hline 5 & $\mathrm{Ph}_{2} \mathrm{Zn}-\left(\mathrm{H}_{4}-\mathrm{Ind}\right){ }_{2} \mathrm{ZrCl}_{2}-\mathrm{MAO}$ & 2.06 & 0.09 & 0.09 & n.d. & n.d. & n.d. & n.d. \\
\hline 6 & $\mathrm{Ph}_{2} \mathrm{Zn}-\left(\mathrm{Bu}{ }^{t} \mathrm{Cp}\right)_{2} \mathrm{ZrCl}_{2}-\mathrm{MAO}$ & 2.68 & 0.14 & 0.17 & n.d. & n.d. & n.d. & n.d. \\
\hline 7 & $\mathrm{Ph}_{2} \mathrm{Zn}-\operatorname{Pr}(\mathrm{Flu})(\mathrm{Cp}) \mathrm{ZrCl}_{2}-\mathrm{MAO}$ & 8.46 & 0.10 & 0.11 & n.d. & n.d. & n.d. & n.d. \\
\hline 8 & $\mathrm{Ph}_{2} \mathrm{Zn}-\mathrm{Et}(\mathrm{Ind})_{2} \mathrm{ZrCl}_{2}-\mathrm{MAO}$ & 3.29 & 0.12 & 0.15 & n.d. & n.d. & n.d. & 13.8 \\
\hline 9 & $\mathrm{Ph}_{2} \mathrm{Zn}-(\mathrm{n}-\mathrm{BuCp})_{2} \mathrm{HfCl}_{2}-\mathrm{MAO}$ & $0.50^{\mathrm{e}}$ & n.d. & n.d. & 94.5 & n.d. & n.d. & n.d. \\
\hline 10 & $\mathrm{Ph}_{2} \mathrm{Zn}-\mathrm{Cp}_{2} \mathrm{TiCl}_{2}-\mathrm{MAO}$ & 9.44 & $0.28^{\mathrm{f}}$ & n.d. & n.d. & 241.4 & 256.6 & 58.3 \\
\hline 11 & $\mathrm{Ph}_{2} \mathrm{Zn}-(\mathrm{n}-\mathrm{BuCp})_{2} \mathrm{TiCl}_{2}-\mathrm{MAO}$ & 7.11 & $0.20^{\mathrm{f}}$ & n.d. & n.d. & 249.4 & 266.0 & 91.7 \\
\hline 12 & $\mathrm{Ph}_{2} \mathrm{Zn}-\mathrm{CpTiCl}_{3}-\mathrm{MAO}$ & $45.70^{\mathrm{e}}$ & $0.23^{\mathrm{f}}$ & n.d. & n.d. & 259.0 & 263.0 & 99.8 \\
\hline
\end{tabular}

a)Polymerization conditions: Total volume $=60 \mathrm{~mL},[\mathrm{~S}]=2,1 \mathrm{~mol} / \mathrm{L},[\mathrm{MAO}]=0,33 \mathrm{~mol} / \mathrm{L}$,

$[\mathrm{Ph} 2 \mathrm{Zn}]=[$ Metallocene $]=2.0 \mathrm{E}-04 \mathrm{~mol} / \mathrm{L}{ }^{\text {b) Based on initial styrene }}$

c) Measured in chloroform at $25{ }^{\circ} \mathrm{C}, *$ Measured in o-dichlorobenzene at $135^{\circ} \mathrm{C}$.

${ }^{d)}$ Boiling-butanoneiinsoluble butanone, ${ }^{\mathrm{e}}$ After only 6 hours at $60{ }^{\circ} \mathrm{C},{ }^{\mathrm{f}} \mathrm{n} . \mathrm{d}$. $=$ not determined

Figure 5, Show the DSC chromatogramans of polystyrene obtained using various ternary $\mathrm{Ph}, \mathrm{Zn}$-titanocene-MAO inititor systems, which compare them with zirconocenes ternary initiator systems : $\mathrm{Ph}_{2} \mathrm{Zn}-\mathrm{Et}(\mathrm{Ind})_{2} \mathrm{Cl}_{2}$. From there it is note that the polystyrene obtained from titanocene initiator systems are all crystalline with a $\mathrm{T}_{\mathrm{m}}$ ca., $250^{\circ} \mathrm{C}$, while when using a zirconocene based initiator system, resulted amorphous polystyrenes (a-PS).

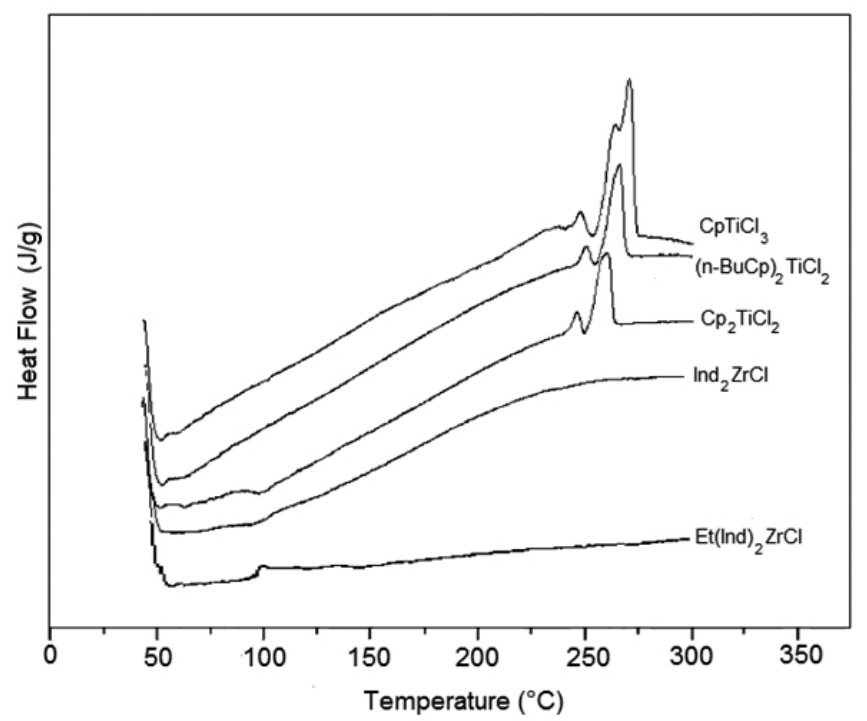

Figure 5. DSC chromatograms of polystyrene obtained using ternary $\mathrm{Ph}_{2} \mathrm{Zn}$-metallocene-MAO initiator System.

From results of Table 5, it become clear that the capacity of $\mathrm{Ph}_{2} \mathrm{Zn}$ matallocene-MAO initiator systems to induce $\mathrm{S} / \mathrm{p}-\mathrm{Bu}$ tS copolymerization increases in the order IndZrCl $<(\mathrm{n}-\mathrm{BuCp})_{2} \mathrm{TiCl}_{2}<\mathrm{CpTiCl}_{3}$. Furthermore, values reported in Table 5 correspond to a 48 hours period of reaction for the first two systems and only to a 6 hours period for the $\mathrm{Ph}_{2} \mathrm{Zn}-\mathrm{CpTiCl}{ }_{3}-\mathrm{MAO}$ initiator system, emphasizing the higher activity of $\mathrm{CpTiCl}_{3}$ when compared with $\mathrm{Ind}_{2} \mathrm{ZrCl}_{2}$ and $(\mathrm{n}-\mathrm{BuCp})_{2} \mathrm{TiCl}_{2}$.

Zambelli et al., [18 b] have established that syndiotactic $\mathrm{S}$ polymerization, using titanocenes-MAO systems, Initiates through coordination of the $\mathrm{S}$ monomer to metal active species. Furthermore, they demonstrated that propagation result from poly-insertion of a $\mathrm{S}$ monomer via secondary insertion.

Taking account these achievement and in concordance of our previous results [10-14] and the present ones, we think that syndiotactic $S$ polymerization catalyzed by our $\mathrm{Ph}_{2} \mathrm{Zn}-\mathrm{CpTiCl}_{3}-\mathrm{MAO}$ initiator system, conversely with Zambelli $[3 \mathrm{~b}, 18 \mathrm{~b}]$ and other authors, proceed through coordination of $\mathrm{S}$ monomer to the active species followed by the insertion of the monomer into the growing chain, propagation goes throughout an ionic pathway. [12, 14]

\section{CONCLUSIONS}

- $\quad$ From present and previous results : We can conclude that the binary Metallocene-MAO and the ternary $\mathrm{Ph}_{2} \mathrm{Zn}-$ Metallocene-MAO initiators sys- tems induce the homo- and the copolymerization of styrene, substituted styrene, and styrene derivatives

- When included a titanocene, these systems generate syndiotactic polystyrene. While zirconocenes produced at the best traces or low percentage of stereoregular PS.

- The molecular weight distribution of polymers, obtained using the present initiator systems, shows values between 1 and 2 , in agreement with a metallocenic polymerization process.

- The I+ inductive effect of substituent at aromatic ring of styrene and on styrene related monomer, when at para-position (phenyl) favors its polymerization through the studied initiator systems, depending their substitution-position at aromatic ring or at carbon double bond of vinyl group of styrene, or the number of substituent, as the polymerization it is affected by electrical and steric hindrance of the vinyl's styrene bond, through which the incoming monomer coordinates to the active species

- The metallocene's efficiency of initiator systems studied follows the order Titanocene $>$ Zirconocene $>$ Hafnocene. 
Table 5. Styrene / p-tert-butylstyrene copolymerization initiated by various ternary $\mathrm{Ph}_{2} \mathrm{Zn}$-metallocene-MAO initiator systems, in toluene at $60{ }^{\circ} \mathrm{C}$ after 48 hours. ${ }^{\text {a }}$

\begin{tabular}{|c|c|c|c|c|c|c|c|c|c|}
\hline \multirow{2}{*}{$\begin{array}{c}\text { Feed } \\
\mathrm{S} / \mathrm{Bu}^{\mathrm{t} S}\end{array}$} & \multicolumn{3}{|c|}{ Ind $_{2} \mathrm{ZrCl}_{2}{ }^{\text {b) }}$} & \multicolumn{3}{|c|}{$(\mathrm{n}-\mathrm{BuCp})_{2} \mathrm{TiCl}_{2}^{\mathrm{b})}$} & \multicolumn{3}{|c|}{$\mathrm{CpTiCl}_{3}{ }^{\mathrm{c}}$} \\
\hline & Conv $^{\mathrm{d})}$ & $|\eta|^{\text {d) }}$ & $\mathrm{T}_{\mathrm{g}}^{\mathrm{e})}$ & Conv $^{\mathrm{d}}$ & $|\eta|^{\mathrm{d})}$ & $\mathrm{T}_{\mathrm{g}}$ & Conv $^{\mathrm{d}}$ & $|\eta|^{\mathrm{d})}$ & $\mathrm{T}_{\mathrm{g}}$ \\
\hline $\mathrm{mol} / \mathrm{mol}$ & $\%$ & $\mathrm{dL} / \mathrm{g}$ & ${ }^{\circ} \mathrm{C}$ & $\%$ & $\mathrm{dL} / \mathrm{g}$ & ${ }^{\circ} \mathrm{C}$ & $\%$ & $\mathrm{dL} / \mathrm{g}$ & ${ }^{\circ} \mathrm{C}$ \\
\hline S only & 8,4 & 0.50 & 102.6 & 17.4 & $0.15^{*}$ & 100.6 & 42.0 & $0.20^{*}$ & 100. \\
\hline $96 / 5$ & n.p. & n.p. & n.p. & n.p. & n.p. & n.p. & 54.1 & $0.22 *$ & 103. \\
\hline $75 / 25$ & 5,0 & 0,52 & 116,9 & 12.6 & $0.36^{*}$ & 116.8 & 68,2 & $0.23 *$ & 118. \\
\hline $60 / 40$ & 4,7 & 0.58 & 123,2 & 8.3 & $0.39^{*}$ & 122.3 & n.p. & n.p. & n.p, \\
\hline $50 / 50$ & 6,3 & 0.52 & 126.8 & 7.5 & $0.46^{*}$ & 127.4 & 70.2 & $0.23 *$ & 129.6 \\
\hline $25 / 75$ & 13,3 & 0.28 & 134,0 & 12.0 & $0.80 *$ & 133.3 & n.p. & n.p. & n.p. \\
\hline $\mathrm{Bu}^{\mathrm{t} S}$ only & 19,6 & 0.29 & 139.2 & 12,4 & 0.80 & 135.4 & 94,0 & $0.22 *$ & 141.6 \\
\hline
\end{tabular}

a) Total volume $=40 \mathrm{ml},[\mathrm{S}]+\left[\mathrm{Bu}^{\mathrm{t}} \mathrm{S}=2.0 \mathrm{~mol}\left(\mathrm{~L},[\mathrm{MAO}]=0,33 \mathrm{~mol} / \mathrm{L},\left[\mathrm{Ph}{ }_{2} \mathrm{Zn}\right]=\right.\right.$ metallocene $=2.0 \times 10^{-4} \mathrm{~mol} / \mathrm{L}$ Polymerization carried in toluene at $60{ }^{\circ} \mathrm{C}$ : ${ }^{\text {b) }}$ Reaction Time 48 h., ${ }^{\text {c) }}$ Reaction Time $6 \mathrm{~h},{ }^{\text {d) }}$ Conversion based on initial feed, e) Measured in chloroform at $25^{\circ} \mathrm{C}$ or in o-dichlorobenzene $(*)$ at $135^{\circ} \mathrm{C}$.

\section{AKNOWLEDGEMENT}

Financial support from the Fondo Nacional de Desarrollo Científico y Tecnológico, FONDECYT, under Projects : 198-1135, 101-0036, and 108-5061, and from the Departamento de Investigaciones Científicas y Tecnológicas, Universidad de Santiago de Chile are gratefully acknowledged. Authors are also grateful to Prof. R. Quijada, Facultad de Ciencias Físicas y Matemáticas, Universidad de Chile, for equipment facilities. And to Profs., S. Muñoz-Guerra and A. Martínez de Ilarduya from Universidad Politëcnica de Catalunya, Barcelona, Spain, for their cooperation. Thanks are due to B.Cs., Graduating students as well to Ms.Cs, and Ph.D. Graduating students performing their studies and experimental research at our Research Group.

\section{REFERENCES}

1.- Google : "Imágenes worldwide production of plastics" 2010

2.- P. Ishihara, T. Seimiya, M. Kuramoto, M. Uoi, (1986) Macromolecules 19: 2464

3.- a) Pellecchia C, Longo P, Grassi A, Ammendola P, Zambelli A,(1987), synthesisof highly syndiotactic polystyrene with organometallic catalysts and monomer insertion. Makromol. Chem. Rapid Commun, 8: 277-279. b) Longo, P., Proto, P., Zambelli, A. (1995) . Makromol. Chem. Phys. 196 : 3015

4.- Nakatami, H. Nitta, K-h, Soga, K. Takata, T. (1997), Polymer 38 : 4751

5.- a) F.M. Rabagliati, R. Quijada, M.V. Cuevas, C.A. Terraza (1996), Polymeriza-tion ofstyreneby diphenylzinc-additive systems. 4. $\mathrm{Ph}_{2} \mathrm{Zn}$ metallocene-MAO sys-tems.Polym.Bull.37: 13-19. b) F,M, Rabagliati, C. A. Terraza,R. Quijada, (1996) "Polymerization of styrene by diphenylzinc-additive systems. Part V. $\mathrm{Ph}_{2} \mathrm{Zn}$ - $\mathrm{Ind}_{2} \mathrm{ZrCl}_{2}-\mathrm{MAO}$ systems" Intern J. PolymerMater,34:163-168. c) F.M. Rabagliati, M. Pérez, H.A. Ayal. C.A. Terraza, R. Quijada.(1997) "Polymeriza-tion of styrene by diphenylzinc-additive systems. Part VI: $\mathrm{Ph}_{2} \mathrm{Zn}-\mathrm{Cp}_{2} \mathrm{TiCl}_{2}-\mathrm{MAO}$ Systems. Polym.Bull. 39:693-699. c) F.M.Rabagliati, M. Pérez, R. Quijada. (1998) "Polymerization of styrene by diphenylzinc additive systems. Part VII: $\mathrm{Ph}_{2} \mathrm{Zn}$-(n-BuCp) ${ }_{2} \mathrm{TiCl}_{2}-\mathrm{MAO}$ systems" Polym.Bull. 41:441-446. d) F.M. Raba- gliati,M. Pérez, R. Cancino, R. Quijada.(1999). "Polymerization of styrene bydiphenylzinc-additive systems. Part IX: New experiment with $\mathrm{Ph}_{2}$ Zn-Met-MAO systems. Polym.Int. 48:681-684.

6. a) F.M.Rabagliati, M. Pérez, M.A, Soto, A. Martínez de Ilarduya, S. Muñoz Guerra.(2001) Copolymerization of styrene by diphenylzincadditive systems. Copolymerization of styrene/p-tert-butylstyrene by $\mathrm{Ph}_{2} \mathrm{Zn}$-metallocene-MAO systems. Eur. Polym. J. 37: 1001-1006. b) F.M.Rabagliati, C.J. Caro, M.A. Pérez, (2002) Copolymerization of styrene by diphenylzinc-additive systems. Part III. Copolymerization of styrene /para-methylstyrene using $\mathrm{CpTiCl}_{3}-\mathrm{MAO}$ and $\mathrm{Ph}_{2} \mathrm{Zn}-\mathrm{CpTiCl}_{3}-$ MAO initiator systems.Bol. Soc. Chil. Quim., 47: 137-144 c) M.A. Pérez, C.J. Caro, R.A. Cancino, F.M. Rabagliati, (2003) Ph Zn-meta-
llocene-MAO initiator systems in the homo- and copolymerization of styrene /p-alkylstyrene". Polym. Bull., 51: 199-208. d) F.M. Rabagliati, M.A. Pérez, R.A.Cancino, F.J. Rodríguez, C.J. Caro. (2003) homoand copolymerization of styrene using combined diphenylzinc-additive initiator systems. Macromol.Symp. 195: 81-88. e) F.M.Rabagliati, M.A. Pérez, R.A. Cancino, M.A. Soto, F.J. Rodríguez, C.J. Caro, A.G. León, H.A. Ayal, R. Quijada, (2001) Polymerization a Co .Macromol.Symp.168: 31-42.

7.- a) F.M. Rabagliati, H.E. Muñoz, G.V. Mardones (2010) Styrene / (styrene-derivative) copolymerization by $\mathrm{Ph}_{2} \mathrm{Zn}$-metallocene-MAO systems : Homo- and copolymerization of methylstyrene wiith styrene. J. Chil. Chem. Soc., 55: 111-114. b) F.M.Rabagliati, M.A. Pérez, F.J.Rodríguez, R.A. Cancino, N. Crispel, G.V. Mardones, H.E. Muñoz, M.A. Saavedra, M.Vidal, L.A. Muñoz. (2011) Further studies on homoand copolymerization of styrene through Metallocenic initiator systems. Macromol Symp., Special Issue: Macromolecular Complexes, 304: 33-39.

8.- a) F.M.Rabagliati, M.A. Pérez, R.A. Cancino, A. Martínez de Ilarduya, S.Muñoz-Guerra (2005) Homo- and copolymerization of styrene and 1-alkene using $\mathrm{Ph}_{2} \mathrm{Zn}$-Et(Ind) $\mathrm{ZrCl}_{2} \quad \mathrm{MAO}$ initiator systems. Eur. Polym. J., 41: 1013-1019. b) R.A. Cancino, F.J. Rodríguez, M.A. Pérez, F.M.Rabagliati (2005) Styrene-alkene copolymerization by $\mathrm{CpTiCl}_{3}$ additive system. J. Ch. Soc., 50: 427-430. c) F.M. Rabagliati, R.A. Cancino, F.J. Rodríguez (2001) "Copolymerization of styrene by diphehylzinc-additive systems. Part II. Copolymerization of styrene / 1-alkene by Ph Zn-metallocene-MAO systems. Polym. Bull. 46:427- 434.

9.- a) F.M.Rabagliati, D.E. Yañez, D.Canales, R.Quijada, P.A. Zapata (2013) Styrene copolymerization using a metallocene-MAO initiator system. Homo- and copolymerization of styrene with some cycloalkenes. Polym. Bull 70:2111-23. b) F.M. Rabagliati, D.A.Canales, D.E. Yañez, P. Zamora, P.A. Zapata. (2013) Further Studies on Homo- and Copolymerization of styrene through $\mathrm{CpTICl}_{3}-\mathrm{MAO}$ initiator system. J. Chil. Chem. Soc, $\mathbf{5 8}$ : 2082-2086. c) F.M. Rabagliati, D.A. Canales, D.E. Yañez, P.A. Zapata, A.Martinez de Ilarduya, S. Muñoz-Guerra. (Submitted 2015) Styrene copolymerization using a metallocene-MAO initiator system.Homo- and copolymerization of styrene with some cycloalkenes through a $\mathrm{CpTiCl3-}$ MAO initiating system.Polym. Bulletin (Submitted dec. 2015)

10.- F.M. Rabagliati, M.A. Pérez, F.J. Rodriguez, R.A. Cancino, N.Crispel, G.A. Mardones, H.E. Muñoz, M.A. Saavedra, M. Vidal, L.A. Muñoz (2011) Further studies on homo- and copolymerization of styrene through metallocenic initiator system.Macromol.Symp.,304; 33--39

11.- F.M. Rabagliati, M.A. Perez, F.J. Rodriguez, C.J. Caro, N. Crispel (2005) Further studies of styrene/(styrene derivative)copolymerizations using combined diphenyl-zinc additive initiator systems. Polym.Int 54: 437-44.

12.- a) L.A. Tamayo, P.A. Zapata, N.D. Vejar, M.I. Azocar. M.A. Gulppi, X. Zhou, G.E. Thompson, F.M. Rabagliati, M.A. Páez (2014) Release of silver and copper nano-particles from polyethylene nanocomposites and their penetration into Listeria moniocytogens. Materials Science 
Engineering 40 : 24-31 b) D.A. Yañez, S. Guerrero, I. Lieberwirth, M.T. Ulloa, T. Gomez. F.M. Rabagliati, P.A. Zapata (2015). Photocata-lytic inhibition of bacteria by $\mathrm{TiO}_{2}$ nanotube-doped polyethylene composites. App. Catal. A : General 489 : $255-261$

13.- a) F.M. Rabagliati, D.E. Yañez, D.Canales, R.Quijada, P.A. Zapata. (2013). "Sty- rene copolymerization using a metallocene-MAO initiator system. Homo- and copolymerization of styrene with some cycloalkenes". Polym. Bull 70: 2111-2123

14.- Patent ; WO 2013029194 : "Use of non-steroidal anti-inflammatory drugs meloxicam and peroxicam, administered intravaginally, for interruption of a woman's ovulation process". Asigned to: Universidad de Santiago de Chile. Date : 07.03.2013 Inventors : H. Cárdenas. H. Croxatto, F. Rabagliati, P. Zapata, P. Gálvez, D. Altabir, L. Velazquez.

15.- F.M. Rabagliati, P.A. Zapata, G.P. Orihuela, P. Gálvez, D. Canales, H. Cárdenas (2014). "Preparation and characterization of a new polymer/ pharmaceutical based composite. Part I : Meloxicam.” Polym. Bull. 71:
3323-3331

16.- O.F. Solomon, B.S. Gotesman (1967).“Calculation of viscosity number from a single measurement .Macomol Chem., 104: 177-18

17.- N. Ishihara, T. Seimiya, M. Kuramoto, M. Uoi (1986) Macromolecules, 19: 2465

18.- a) C.Pellecchia, P. Longo, A. Grassi, P. Ammendola, A. Zambelli, Makromol. Chem., Rapid Commun.,8: 277 (1987). b) P. Ammendola, C. Pellecchia, P. Longo, A. Zambelli. Gazz.Chim. Ital., 117: 65 (1987)

19.- a) A.Kucht, H.Kucht, S.Barry, J.C.W. Chien, M.D. Rausch Organometallics 12, 3075 (1993). b) M. L. Dias, A.Giarruso, L.Porri, Macromolecules 26, 6664 (1993). c) N.Ishihara, M. Kuramoto, in Catalyst Design for TailorMade Polyolefins, Kodans (Tokyo)-Elsevier, (K.Soga and M. Terano, Eds.), 339 (1994) b) C .Pellecchia, Longo P,Grassi A, Ammendola P, Zambelli A(1987), Synthesis of highly syndiotactic poly-styrene with organometallic catalysts and monomer Insertion. MakromolChem Rapid Commun, 8: 277-279. 